\title{
The Influence of Genome and Cell Size on Brain Morphology in Amphibians
}

\author{
Gerhard Roth ${ }^{1}$ and Wolfgang Walkowiak ${ }^{2}$ \\ ${ }^{1}$ University of Bremen, Brain Research Institute, D-283345 Bremen, Germany \\ ${ }^{2}$ University of Cologne, Biocenter, Institute for Zoology, D-50674 Köln, Germany \\ Correspondence: gerhard.roth@uni-bremen.de; w.walkowiak@uni-koeln.de
}

In amphibians, nerve cell size is highly correlated with genome size, and increases in genome and cell size cause a retardation of the rate of development of nervous (as well as nonnervous) tissue leading to secondary simplification. This yields an inverse relationship between genome and cell size on the one hand and morphological complexity of the tectum mesencephali as the main visual center, the size of the torus semicircularis as the main auditory center, the size of the amphibian papilla as an important peripheral auditory structure, and the size of the cerebellum as a major sensorimotor center. Nervous structures developing later (e.g., torus and cerebellum) are more affected by secondary simplification than those that develop earlier (e.g., the tectum). This effect is more prominent in salamanders and caecilians than in frogs owing to larger genome and cells sizes in the former two taxa. We hypothesize that because of intragenomic evolutionary processes, important differences in brain morphology can arise independently of specific environmental selection.

\begin{abstract}
$A^{1 l}$ vertebrate brains possess fundamental orAganizational features. Nonetheless, they display great taxonomic variation. Brains not only differ in absolute and relative size, but also in morphological complexity across, as well as within, classes, orders, and even families. Morphological complexity may be characterized by the number of anatomically distinct nuclei, the degree of lamination of specific parts of the brain (e.g., dorsal pallium, mesencephalic tectum, thalamic nuclei), the number of different cells types, and the degree and pattern of neuronal connectivity (Nieuwenhuys et al. 1998).

Traditionally, brain differences are considered to have resulted from environmental selection so that brain complexity may have been
\end{abstract}

favored by the demands imposed by environmental complexity. Alternatively, some of the observed morphological differences may have arisen independently of specific environmental selection. Increases in brain complexity may have allowed certain species to enter new ecological niches or to develop new lifestyles and thereby escape competition (cf. Roth 2013). One rationale for this hypothesis is the fact that substantial changes in brain morphology usually occur too slowly to be the result of rapid adaptation to a new environment. Thus, causes for such changes would be nonselective, at least with respect to the new environment.

Here, we argue that the morphological complexity of brains in amphibians (and in lung-

Editors: Rebecca Heald, Iswar K. Hariharan, and David B. Wake

Additional Perspectives on Size Control in Biology: From Organelles to Organisms available at www.cshperspectives.org

Copyright (C) 2015 Cold Spring Harbor Laboratory Press; all rights reserved; doi: 10.1101/cshperspect.a019075

Cite this article as Cold Spring Harb Perspect Biol 2015;7:a019075 
fishes) is substantially influenced by genome size and cell size. The changes resulting from these factors, rather than directing environmental selection, "canalize" adaptive processes (Wake and Roth 1989). This process leads to secondary simplification of morphology in the context of "paedomorphosis," a form of heterochronic development, in which traits that characterize juvenile or "larval" stages of ancestral taxa appear in the adult stage of descendant taxa (Wake 1966; Gould 1977; Alberch et al. 1979).

Modern amphibians are represented by the subclass Lissamphibia (i.e., smooth-skinned amphibians), which, according to present taxonomy, comprises three orders: frogs (Anura, with 55 families and 6439 described species), salamanders and newts (Caudata, with 10 families and 668 described species), and caecilians (Gymnophiona, with 10 families and 200 described species) (amphibiaweb.org). Anurans are found worldwide with the exception of Arctic and Antarctic regions, whereas salamanders are found only in the Northern hemisphere of North America and Eurasia, as well as in Central America and northern parts of South America. Caecilians are found only in the tropics and subtropics of Eurasia, Africa, and America. Molecular evidence shows that Caudata and Anura are sister taxa, and Gymnophiona is sister to them (Shen et al. 2013).

Vertebrates differ dramatically in genome size (i.e., the amount of DNA). The smallest genome is found in teleost fishes, with $<1 \mathrm{pg}$ DNA per haploid genome (Olmo 1983; Morescalchi 1990; Gregory 2005a,b). Amniote genome sizes are also relatively small and range from 0.9 to 5.5 pg DNA (Olmo 1983). The largest genome sizes among vertebrates and animals in general are found in lungfishes (Dipnoi), with $111 \mathrm{pg}$ in Lepidosiren, $142 \mathrm{pg}$ in Protopterus, and 80 pg in Neoceratodus (Northcutt 1987). Among anurans, genome size ranges between $1.01 \mathrm{pg}$ (Scaphiopus couchi; Animal Genome Size Database, www.genomesize.com; last accessed $\mathrm{Au}$ gust 2014) and 19 pg (Arenophryne rotunda) (Mahony 1986). Salamanders have genome sizes between $13.9 \mathrm{pg}$ (Desmognathus wrighti) and $83 \mathrm{pg}$ (Necturus maculosus), and caecilians have genome sizes ranging from 8 to $26 \mathrm{pg}$.
The plethodontid species Hydromantes italicus (72 pg) appears to have the largest genome of any terrestrial animal, although several tropical plethodontids approach this value (cf. Table 1).

In amphibians, as well as in some other groups of vertebrates, genome size determines cell size (i.e., volume) by the fact that large amounts of DNA appear to require large nuclei and, consequently, large cell volumes (Ohno 1970; Szarski 1970, 1983; Olmo and Morescalchi 1975, 1978; Vinogradov 2004; Gregory 2005a). In salamanders, average cell size varies from $7.2 \mu \mathrm{m}$ in diameter in Desmognathus ochrophaeus to $15.1 \mu \mathrm{m}$ in Hydromantes genei. In frogs, the smallest cell size of $5.1 \mu \mathrm{m}$ is found in the miniaturized Eleutherodactylus (formerly Sminthillus) limbatus, and the largest of $10 \mu \mathrm{m}$ in A. rotunda. Genome and cell size are assumed to significantly affect, in an inverse manner, (1) metabolic rates, (2) number of cells, (3) speed of growth, and (4) differentiation processes including cell cycle time (Horner and MacGregor 1983; Sessions and Larson 1987; Jokusch 1997; Chipman et al. 2001). Consequently, amphibians with large genome and cell sizes are expected to show low metabolic rates, slow growth and differentiation processes, and a relatively low number of cells, including neurons (Gregory 2005a).

\section{GENOME SIZE, NERVE CELL SIZE, AND BRAIN COMPLEXITY}

When compared with the brains of cartilaginous and bony fish and all amniotes, amphibian brains show a relatively simple, "embryonic" or "larval-like" morphology. Within amphibians, frogs generally display a more complex brain morphology than salamanders (Dicke and Roth 2007). In frogs, we find morphologically distinct nuclei that often lie in migrated positions in the diencephalon, the pretectum, torus semicircularis, and mesencephalic tegmentum. In addition, multiple lamination (i.e., an alternation of cellular and fibrous layers) is found in the tectum mesencephali and in a number of diencephalic nuclei, whereas in salamanders, cell migration and lamination is much reduced or even completely absent. Finally, frogs have 


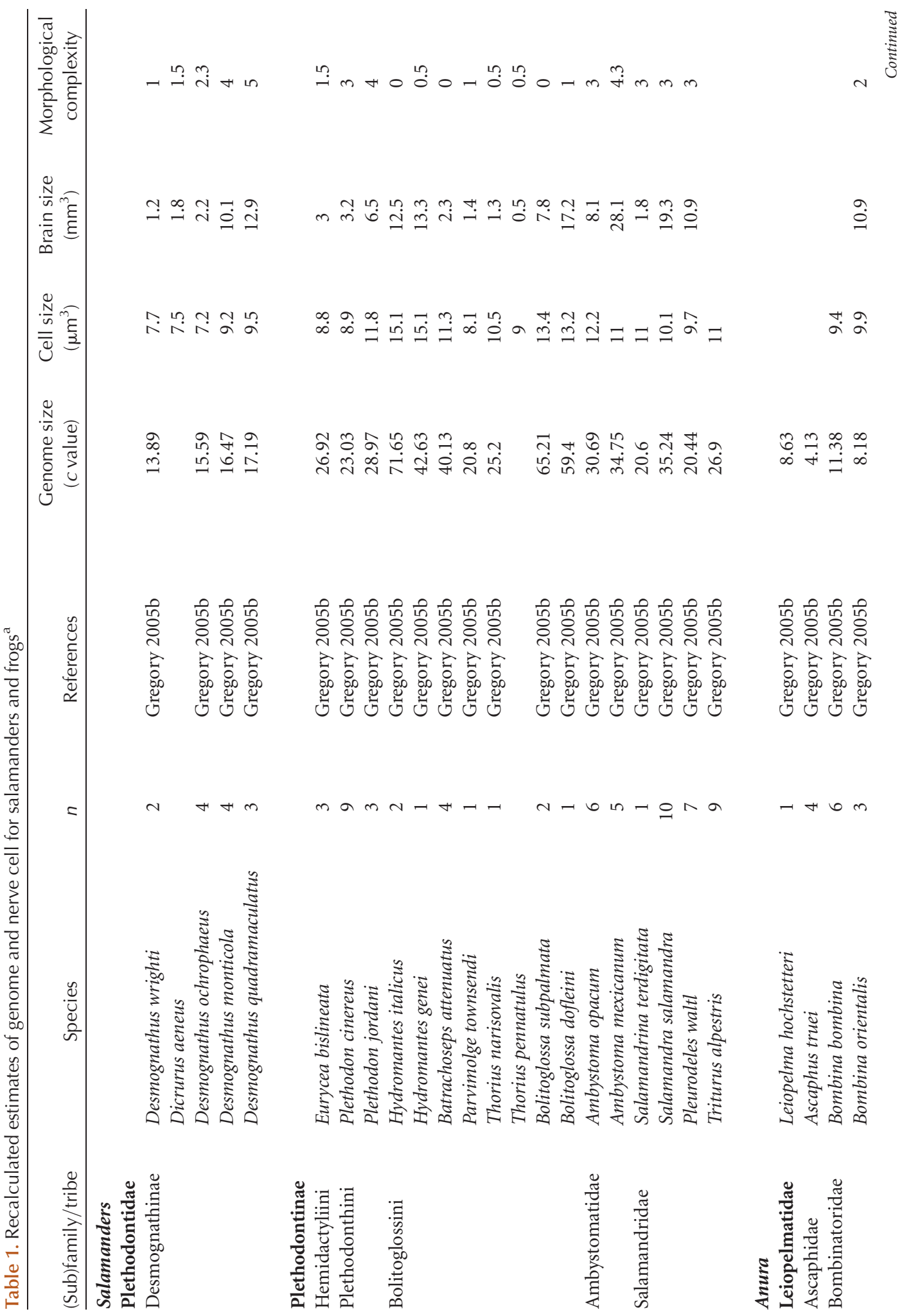




\section{G. Roth and W. Walkowiak}
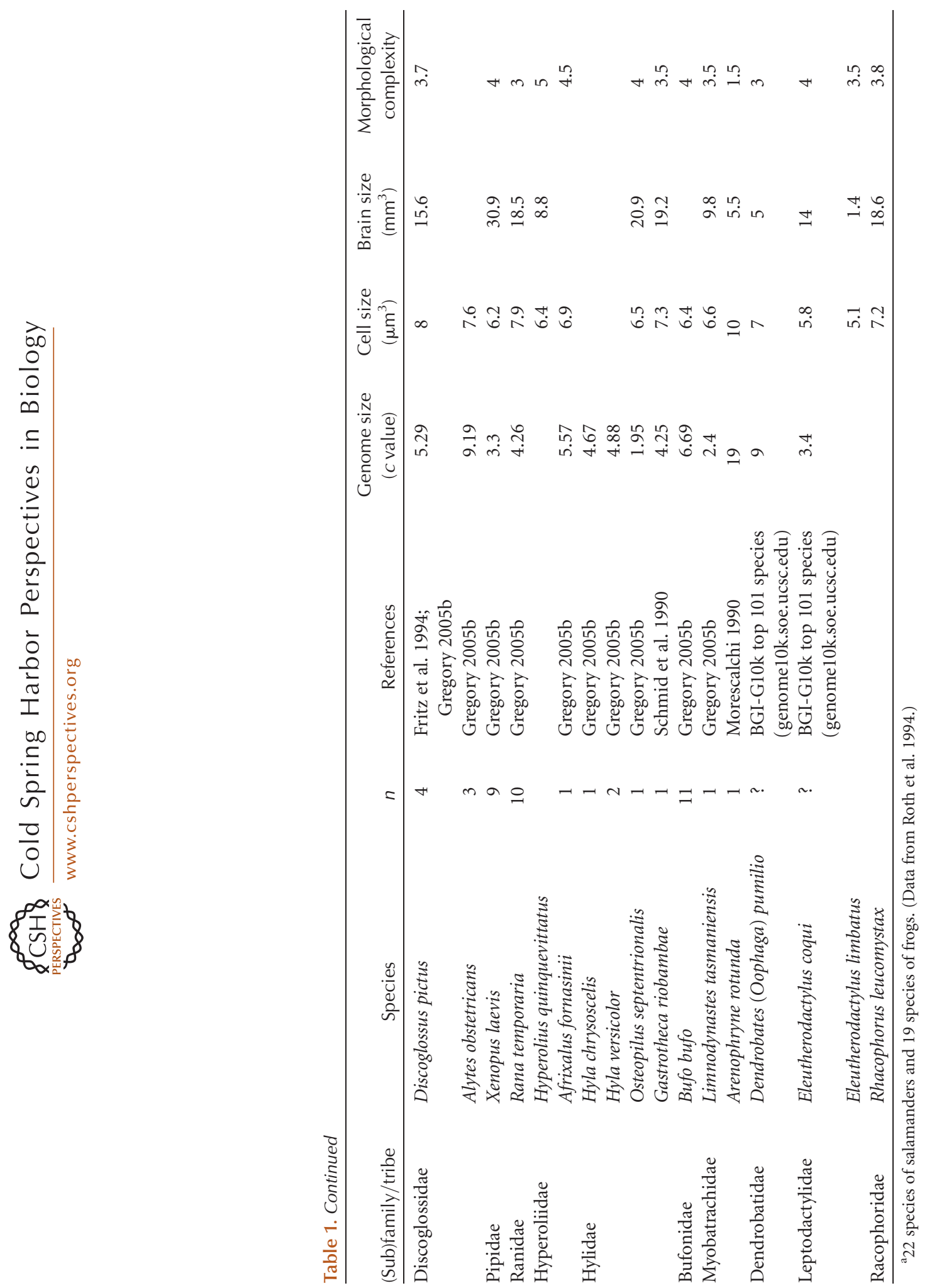
well-developed and laminated cerebella, whereas in salamanders, the corpus cerebelli is very small, or the auricles form a paired structure without a fusion in the midline (ten Donkelaar 1998b). Caecilians show a situation very similar to that found in salamanders.

Here, we argue that in amphibians the seemingly simple or primitive brain morphology is the result of secondary simplification caused by an increase in genome size, which in turn leads to an increase in cell size and, consequently, retardation of the development of the brain and other traits. Furthermore, we argue that brain traits appearing late in development are more affected by such retardation than those appearing early. In general, secondary simplification is expected to be more prominent in urodeles than in anurans because of the much larger genome and cell sizes in the former.

To support these ideas, we review data that relate genome size, cell size, and the morphological complexity of prominent parts of the amphibian brain, such as the tectum mesencephali ("optic tectum") and torus semicircularis. These areas are the major brain centers for processing visual and acoustic information, respectively. In addition, we provide estimates for the size of the cerebellum, which is important for sensorimotor coordination and the number of hair cells in a special region of the amphibian papilla, an inner ear organ particular to anurans.

\section{Genome Size and Nerve Cell Size}

In Table 1, we show recalculated estimates of genome and nerve cell size from Roth et al. (1994) for 22 species of salamanders and 19 species of frogs. In Figure 4, we plot data from Table 1. In Figure 4A, a significant positive correlation is evident between genome size and nerve cell size in both frogs and salamanders. Thus, species from both groups with larger genome sizes generally have larger nerve cells.

\section{Tectum Mesencephali}

Complexity of the tectum mesencephali was judged on the basis of the degree of lamination (i.e., the number of alternating cell and fiber layers) in the midbrain tectum, the main visual center of these animals (see examples in Fig. 1 and Dicke and Roth 2007). For correlational analyses among nerve cell size, brain size and morphological complexity of the tectum, we defined five classes in frogs and six classes in salamanders. The classes range from class 1 , which represents the most undifferentiated state of the tectum, to class 5 or 6 , which represent the most differentiated state (for details see Roth et al. 1994).

In frogs, four groups of species were recognized regarding morphological complexity of the tectum. The first group contains frogs with large to very large nerve cells (i.e., A. rotunda) (10 $\mu \mathrm{m}$ average cell diameter) Bombina bombina $(9.4 \mu \mathrm{m})$, and Bombina orientalis $(9.9 \mu \mathrm{m})$. Their tecta have an average rank of morphological complexity of 1.5-2.0 according to the criteria mentioned above. Thus, these three species have the least differentiated anuran tecta. Brain size of these species ranges from very small to intermediate sizes (i.e., from 5.5 to $10.9 \mathrm{~mm}^{3}$ ).

The next group contains species that have intermediate nerve cell sizes (i.e., Gastrotheca riobambae, Dendrobates pumilio, and Discoglossus pictus (average cell diameter $7.4 \mu \mathrm{m}$ ). Morphological complexity of the tectum is intermediate and ranks 3.0-3.7. The brain size of these species ranges between 5.0 and $19.2 \mathrm{~mm}^{3}$.

The next group comprises frogs with medium to small nerve cells (i.e., Mantella cowanii, Rhacophorus leucomystax, Rana temporaria, Limnodynastes tasmaniensis, and Osteopilus (formerly Hyla) septentrionalis) (average cell diameter $6.8 \mu \mathrm{m}$ ). Tectal morphology ranks 3.0-4.2 in complexity. Eleutherodactylus limbatus is included in this group based on its complexity score, but it has the smallest cells found among frogs (cell diameter $5.1 \mu \mathrm{m}$ ). E. limbatus is a true miniaturized species $(11.7 \mathrm{~mm}$ snoutvent length $[\mathrm{SVL}])$, and it has by far the smallest brain among anurans sampled $\left(1.4 \mu \mathrm{m}^{3}\right)$. Brain sizes in the other species range between 5.4 and $20.9 \mathrm{~mm}^{3}$.

The last group comprises frogs that have small to very small nerve cells: Hyperolius quinquevittatus, Xenopus laevis, Eleutherodactylus coqui, and Mantella aurantiaca (average cell di- 

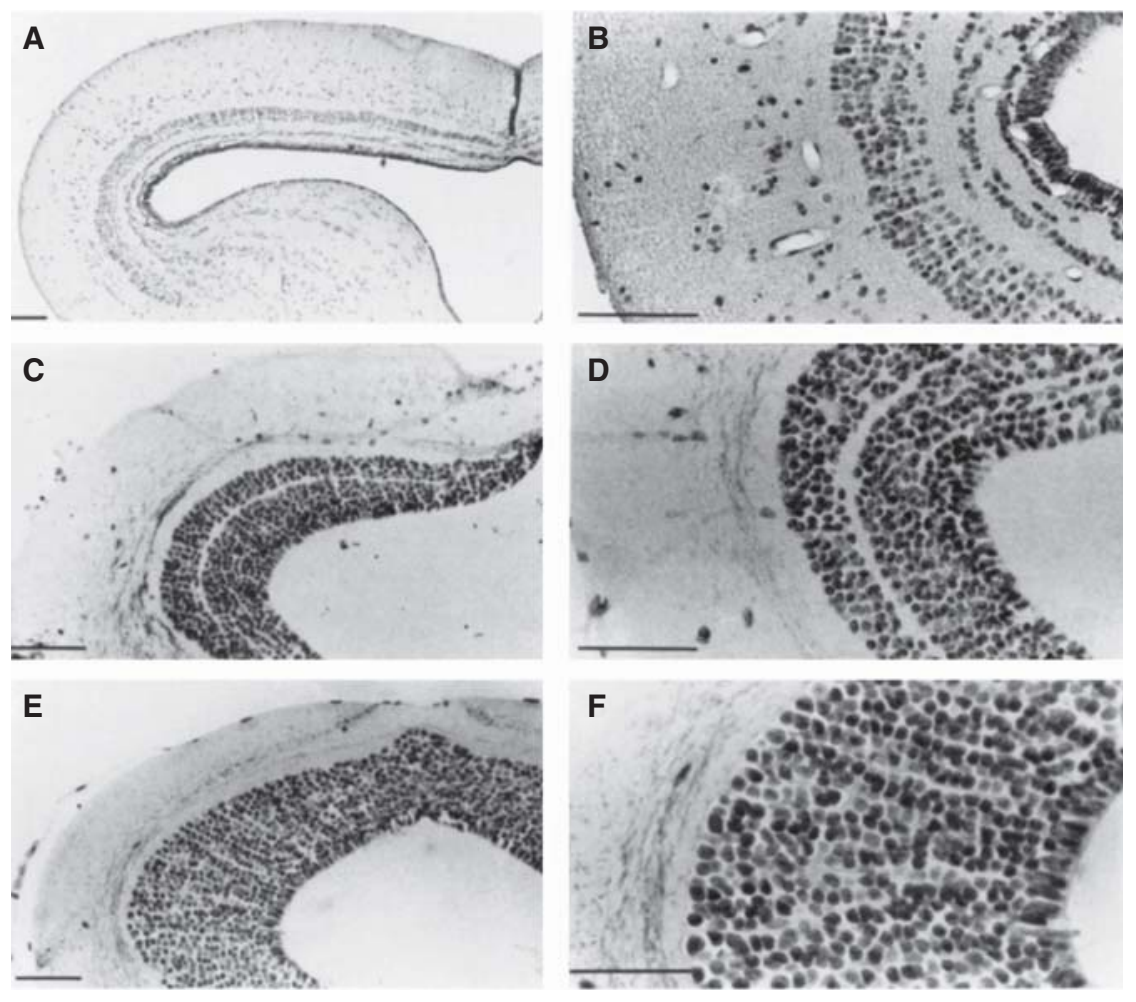

Figure 1. Morphology of the tectum mesencephali in the toad Bufo bufo $(A, B)$, in the salamander Desmognathus quadramaculatus $(C, D)$, and the salamander Hydromante italicus $(E, F)$. B. bufo is characterized by a relatively small genome and small nerve cells and has a highly laminated tectum. Desmognathus quadramaculatus has a relatively small genome and relatively small cells compared with other salamanders and, accordingly, has one of the most structured salamander tecta. $H$. italicus has the largest genome among terrestrial vertebrates and very large cells, and its tectal morphology appears to be very simple because of the absence of any lamination. Scale bar, $100 \mu \mathrm{m}$. (From Roth et al. 1993; reprinted, with permission, from the authors.)

ameter $6.1 \mu \mathrm{m})$. Their tectal morphology ranks $4-5$ in complexity, and their brain size ranges from 5.3 to $30.9 \mathrm{~mm}^{3}$.

Thus, in frogs, morphological complexity of the anuran tectum is significantly negatively correlated with cell size $(r=-0.777, p<0.01)$. Frogs with smaller cells have more complex tecta (Fig. 4B). However, brain size and body size are uncorrelated with genome or nerve cell size with the exception that species with very large genome and nerve cell sizes tend to have small brains, in addition to low tectal complexity.

In salamanders, four groups were recognized. The most undifferentiated tectum (average rank per species $0-0.5$ ) is associated with nerve cells of medium to large size (diameters $9.0-11.3 \mu \mathrm{m}$ ) and found in small to miniatur- ized species (13-42 mm SVL) - Thorius narisovalis, Thorius pennatulus, and Batrachoseps attenuates. Brain sizes range from 0 to $2.3 \mathrm{~mm}^{3}$. The second group also has relatively undifferentiated tecta $(0-1)$ and even larger cells (diameters $13.2-15.1 \mu \mathrm{m})$; species in this group are medium-sized to large ( $>45 \mathrm{~mm} \mathrm{SVL})-$ Bolitoglossa pesrubra (formerly subpalmata), Bolitoglossa dofleini, $H$. italicus, and $H$. genei. Brain size ranges from 7.8 to $17.2 \mathrm{~mm}^{3}$. A third group has more differentiated tecta (rank 1-3), but cells are of small to medium cell size (diameters 7.2-11.0 $\mu \mathrm{m}$ ); members of this group are small ( $<42 \mathrm{~mm} \mathrm{SVL}$ - Desmognathus wrighti, Dicrurus aeneus, D. ochrophaeus, Parvimolge townsendi, Salamandrina terdigitata, Plethodon cinereus, and Eurycea bislineata. Brain sizes 
range from 1.2 to $3.2 \mathrm{~mm}^{3}$. The fourth group has the best developed tecta (rank 3-5) and cells that are of intermediate size (diameters 9.2-12.2 $\mu \mathrm{m}$ ); species of this group are large to very large (>64 mm SVL)—Desmognathus monticola, Desmognathus quadramaculatus, Plethodon jordani, Salamandra salamandra, Pleurodeles waltl, Ambystoma opacum, and Ambystoma mexicanum. Brain size ranges from 6.5 to $21.1 \mathrm{~mm}^{3}$.

Thus, in salamanders too, the degree of morphological complexity of the tectum is significantly negatively correlated with genome size in the sense that salamanders with smaller cells have more complex tecta (Fig. 4B).

\section{Torus Semicircularis}

In seven anuran species, the relative dimensions of the torus as well as the cerebellum were de-
Genome Size, Cell Size, and Brain Morphology

termined by calculating the ratio of the brain length (measured from the olfactory bulb to the sulcus between tecta and cerebellum) to the maximum rostrocaudal extension of the torus and the maximum dorsoventral extension of the cerebellum, respectively (Fig. 2; cf. Table 2).

In the anuran species studied, the length of the torus is negatively correlated with genome size, which means that species with larger genome sizes have a shorter torus than those with smaller genome sizes. This correlation is significant (Fig. 5A). In anurans, an anatomically distinct, migrated torus semicircularis is present and consists of five subnuclei with extensive cell migration and lamination (Potter 1965; Feng 1983). Three of the nuclei are involved in auditory processing, but receive other sensory input and descending input from diencephalic and telencephalic sources as well (Potter 1965;
A

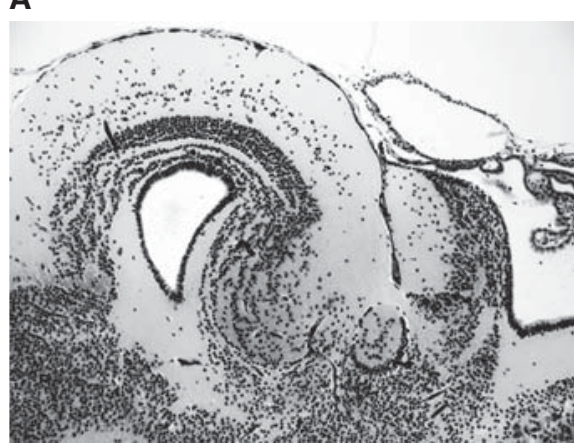

c

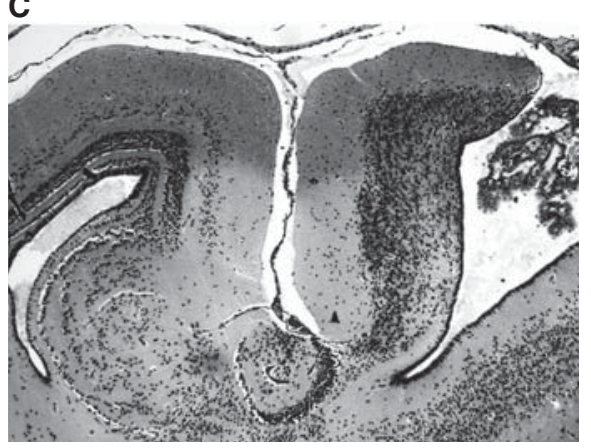

B
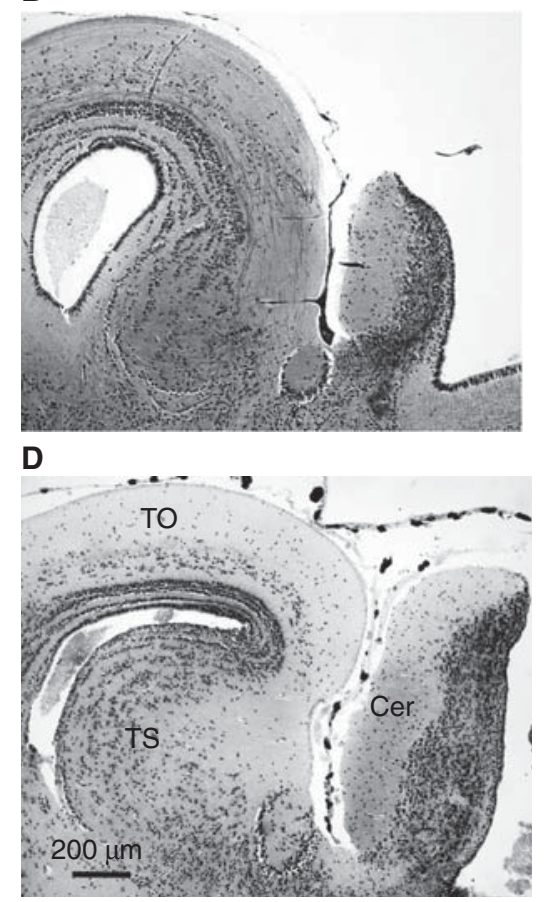

Figure 2. Sagittal sections through the dorsal midbrain/cerebellar area of four different species. (A) Bombina bombina (11.38 pg DNA/n), (B) Discoglossus pictus (5.29 pg DNA/n), (C) Hyla chrysoscelis (4.67 pg DNA/n), and $(D)$ Rana temporaria (4.26 pg DNA/ $n$ ). Calibration bar fits to all subfigures. TO, tectum opticum; TS, torus semicircularis; Cer, cerebellum. 
G. Roth and W. Walkowiak

Table 2. Relative dimensions of torus and cerebellum

\begin{tabular}{|c|c|c|c|c|c|c|c|c|}
\hline Family & Species & $n$ & $\begin{array}{l}\text { Genome } \\
\text { size }\end{array}$ & $\begin{array}{l}\text { Brain length } \\
\quad(\mu \mathrm{m})\end{array}$ & $\begin{array}{l}\text { Torus } \\
(\mu \mathrm{m})\end{array}$ & $\begin{array}{l}\text { Cerebellum } \\
\qquad(\mu \mathrm{m})\end{array}$ & $\begin{array}{l}\text { Brain/ } \\
\text { torus }\end{array}$ & $\begin{array}{c}\text { Brain/ } \\
\text { cerebellum }\end{array}$ \\
\hline \multirow[t]{2}{*}{ Bombinatoridae } & B. bombina & 2 & 11.38 & 4676 & 503 & 515 & 9.29 & 9.08 \\
\hline & B. orientalis & 2 & 8.18 & 4736 & 469 & 566 & 10.10 & 8.37 \\
\hline \multirow[t]{2}{*}{ Discoglossidae } & D. pictus, & 1 & 5.29 & 4909 & 581 & 649 & 8.45 & 7.56 \\
\hline & $\begin{array}{l}\text { Alytes } \\
\quad \text { obstetricans }\end{array}$ & 2 & 9.17 & 4840 & 467 & 534 & 10.37 & 9.06 \\
\hline Ranidae & R. temporaria & 1 & 4.35 & 6675 & 871 & 1173 & 7.67 & 5.69 \\
\hline Hyperoliidae & $\begin{array}{l}\text { Afrixalus } \\
\quad \text { fornasinii }\end{array}$ & 4 & 5.57 & 4028 & 496 & 700 & 8.12 & 5.76 \\
\hline Hylidae & H. chrysoscelis & 1 & 4.67 & 5461 & 652 & 841 & 8.38 & 6.49 \\
\hline
\end{tabular}

In seven species, the relative dimensions of the torus as well as the cerebellum were determined by calculating the ratio of the brain length (measured from the olfactory bulb to the sulcus between tecta and cerebellum) to the maximum rostrocaudal extension of the torus and the maximum dorsoventral extension of the cerebellum.

Endepols and Walkowiak 2000; Wilczynski and Endepols 2007). The principal nucleus with clusters of cells forms the central core of the torus. The laminar nucleus surrounds the principal nucleus rostrally and laterally in an onionskin-like manner. The magnocellular nucleus occupies a caudal or caudolateral portion of the torus.

Neurons of the torus are differentiated by their arrangement as well as by their dimensions, cytoarchitecture, and projection patterns (Feng 1983; Luksch and Walkowiak 1998). The bulk of auditory afferents terminates in the principal nucleus with projections that mainly terminate at the mesencephalic level. In contrast, magnocellular neurons and especially laminar nucleus neurons do not only project to other auditory centers, but also to premotor and motor centers in the brainstem and medulla oblongata, thus forming an audiomotor interface (Walkowiak and Luksch 1994; Luksch and Walkowiak 1998; Wilczynski and Ryan 2010). Single-unit (Hermes et al. 1982), as well as multiunit studies (Mohneke 1983; Schneichel and Schneider 1988) revealed a topic representation of tones in the torus. Low frequencies are represented most caudally; mid- and higher frequencies are represented along a caudorostral axis. The midbrain tonotopic representation appears to be correlated with the dimensions of the amphibian papilla and cytoarchitecture of the torus ( $\mathrm{W}$ Walkowiak, unpubl.).
In urodeles, the region in the caudal mesencephalon corresponding to the torus semicircularis of anurans is morphologically indistinct. It consists of densely packed periventricular neurons without any lamination (Dicke and Roth 2007). This corresponds well with the fact that audition plays no role in the communicative behavior of salamanders.

\section{Cerebellum}

Compared with other tetrapods, the cerebellum of amphibians is small to very small. In most anurans, it consists of a plate-like central part, the corpus cerebelli, and two lateral auricular lobes (ten Donkelaar 1998a,b). Histologically, three layers can be distinguished in the amphibian corpus cerebelli. The molecular layer is the most rostral one and consists mainly of fibers and only few neurons. The most caudal layer (i.e., the granular layer), is densely packed with small cells. In between, a layer of large cells, the Purkinje cells, is located.

The cerebellum of salamanders is small and inconspicuous (Dicke and Roth 2007). It consists of lateral auricles and a simply organized medial corpus cerebelli. No cortical structure is detectable. In urodeles with very large genome sizes (e.g., N. maculosus, Amphiuma means) as well as in small-sized species, the corpus cerebelli is still a paired structure constituting the auricles. The least conspicuous cerebellum 
among amphibians is found in bolitoglossine salamanders, in which it is very small and has partly retreated under the tectum. In larger urodeles with relatively small genome sizes (e.g., A. mexicanum with $34.75 \mathrm{pg}$ ) as well as in all anuran species studied, the bilateral halves are fused forming a massive corpus cerebelli.

In anurans, the rostrocaudal and dorsoventral extensions of the corpus cerebelli related to the length of the brain (see above) are significantly negatively correlated with genome size (Fig. 5B) (i.e., in species with large genome size, the corpus cerebelli is smaller, whereas in those with small genome size, it is larger).

\section{Amphibian Papilla}

To evaluate the correlation between genome size and the number of hair cells in the amphibian papilla, cell counts were taken from the literature (Lewis et al. 1992). To avoid the confounding effects of body size differences among species, the ratio of the caudal extension of the amphibian papilla (region $\mathrm{C}$ in Fig. 3), which shows the greatest species differences to region $\mathrm{B}$, was calculated.

Anuran species possess four sensory epithelia, which are sensitive to distinct frequency ranges of acoustic stimuli. These are the amphibian papilla (sensitive to low to mid-frequencies), basilar papilla (sensitive to high fre- quencies), the sacculus that covers frequencies below those of the amphibian papilla, and the lagena, which is partly an acoustic and partly an equilibrium sensor.

The amphibian papilla can be separated into three distinct regions, according to the shape and arrangement of hair cells denoted by regions $\mathrm{A}, \mathrm{B}$, and $\mathrm{C}$ in Figure 3. A line that corresponds to the position of the diaphragm subdivides regions $B$ in the middle and $C$ in the caudal extension. Regions $\mathrm{A}$ and $\mathrm{B}$ are more or less conserved among anuran species except in the most primitive living frogs Ascaphus truei (Ascaphidae) and Leiopelma hochstetteri (Leiopelmatidae) (Lewis 1984).

In urodeles too, only region $\mathrm{A}$ is found in the amphibian papilla (Lewis and Narins 1999). The length of the caudal extension and the number of hair cells, respectively, are extremely variable from species to species. Region C may even be lacking in some archaeobatrachian anurans (e.g., B. orientalis) (Lewis et al. 1992). In regions $\mathrm{B}$ and $\mathrm{C}$, sound frequencies are tonotopically organized. It is plausible to assume that auditory range and/or quality of the spectral analysis of an acoustic signal are correlated with the dimension of the caudal extension.

Using the ratio of regions $C$ to $B$, the number of hair cells of the amphibian papillae of 26 species is significantly negatively correlated with genome size (Fig. 5C; Table 3). Members of the permanent aquatic family Pipidae have not

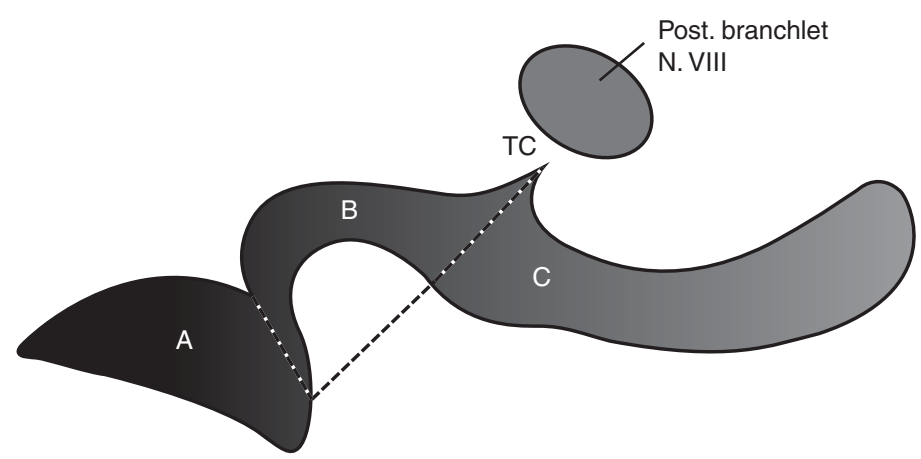

Figure 3. Schematic outline of an amphibian papilla from the left ear of a neobatrachian species. Schematic outline comprising three patches: A, B, and C. A line from the tectorial corner (TC) to the caudomedial end of region A divides region $B$ from $C$. This line corresponds to the thin diaphragm that spans the papillar chamber. (Modified after Lewis et al. 1992.) 
G. Roth and W. Walkowiak
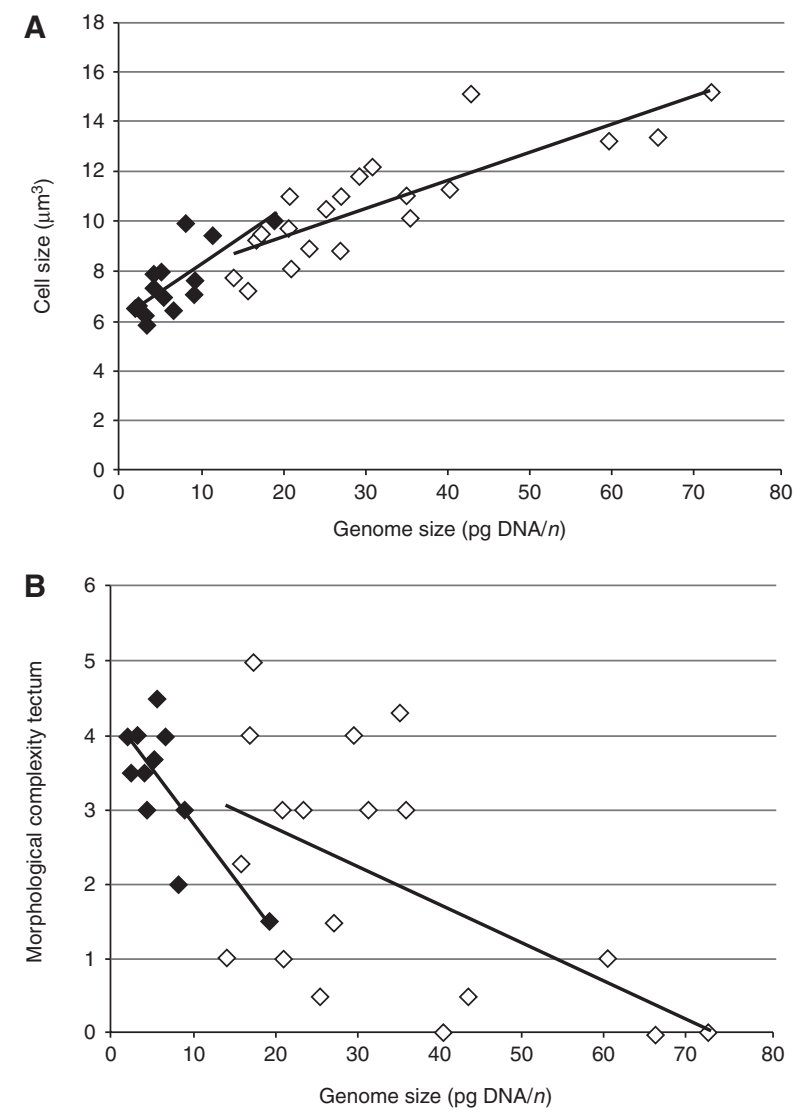

Figure 4. Correlation between genome sizes, cell sizes, and morphological complexity of the mesencephalic tectum. Filled diamond, anurans; open diamond, urodeles. Correlation coefficient $(r)$ and probability of $\alpha$ error $(p)$ are indicated. $(A)$ Correlation with cell size in anurans $(r=0.753, p<0.01)$ and urodeles $(r=0.835$, $p<0.01)$. (B) Correlation with morphological complexity in anurans $(r=-0.772, p<0.01)$ and urodeles $(r=-0.552, p<0.05$. $)$

been included. The papilla amphibiorum is also reduced in size in salamanders in general and in plethodontid salamanders in particular (Lombard 1977).

\section{DISCUSSION}

The data presented here confirm that nerve cell size is highly significantly correlated with genome size in anurans and urodeles. Furthermore, in both groups of amphibians, the morphological complexity of the tectum is highly significantly negatively correlated with genome size. Frogs with very small genomes and cells have the most complex tecta (e.g., E. coqui and Bufo bufo) (Fig. 1A,B), whereas the least com- plex morphologies of the tectum and other parts of the brain are found in A. rotunda and B. orientalis-two unrelated species that have the largest and second largest genomes and cell sizes among the frogs studied. In general, tecta of frogs are morphologically much more complex than those of all salamanders, which corresponds with the fact that, on average, frogs have much smaller genome and cell sizes than salamanders. In salamanders too, species with relatively small genomes and cells have the most complex brains, whereas species with relatively large cells and very large genomes have relatively simple brain morphologies. Although in anurans there is no correlation between genome-cell size and body-brain size, in sala- 
Genome Size, Cell Size, and Brain Morphology
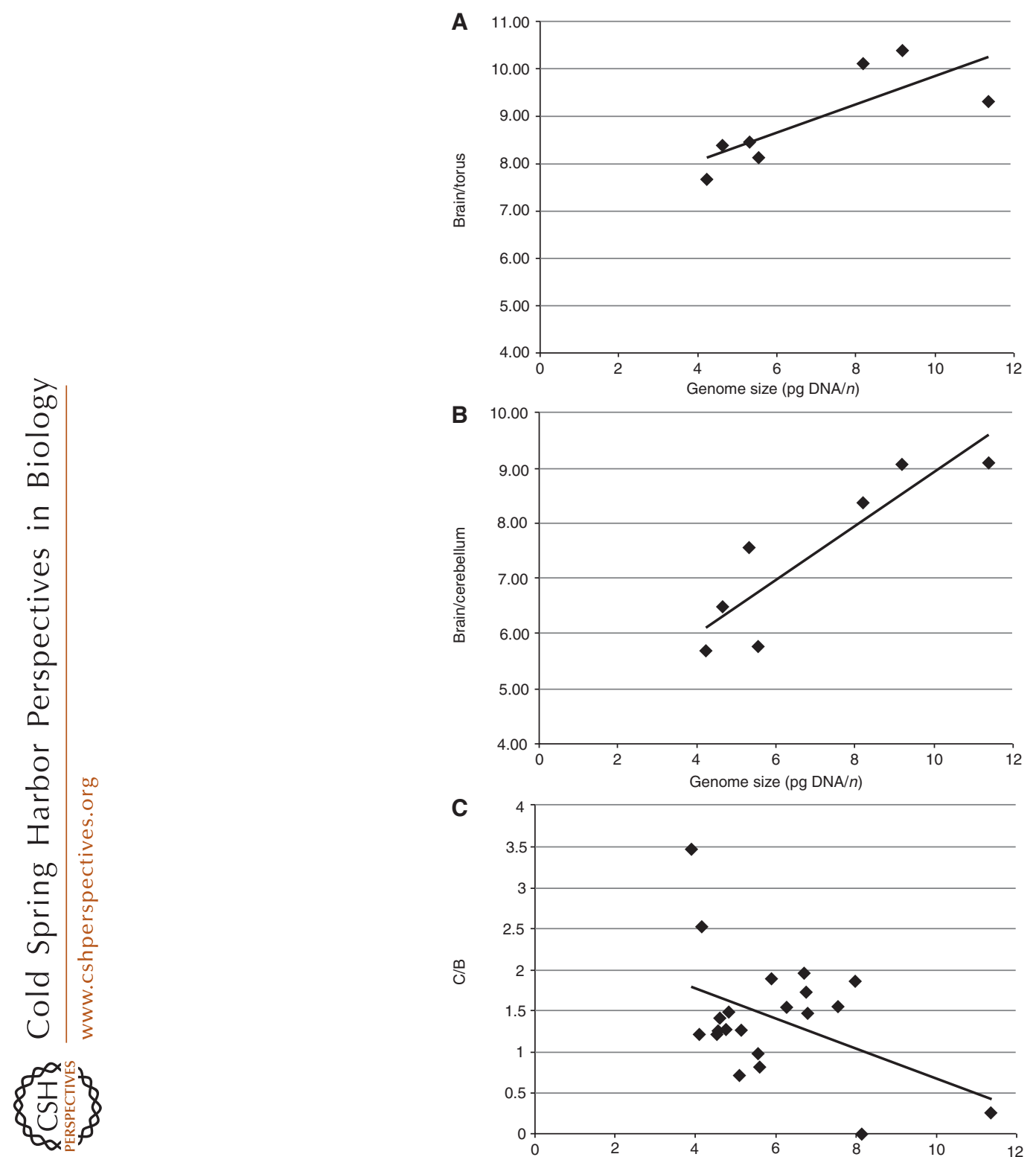

C

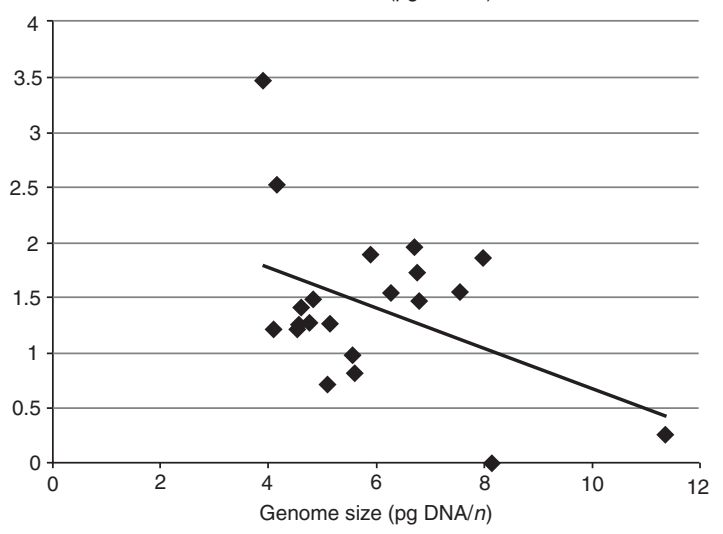

Figure 5. Correlation between anuran genome size. (A) Ratio of brain length to torus extension $(r=0.776, p<$ 0.05). (B) Ratio of brain length to cerebellum extension $(r=0.891, p<0.01)$. ( $C$ ) Ratio of papilla amphibiorum region $\mathrm{C}$ to $\mathrm{B}(r=-0.443, p<0.05)$.

manders we find a complex interaction between these parameters in the sense that smaller species with smaller brains tend to have larger nerve cells and genomes, and larger species with larger brains tend to have smaller genomes and nerve cells. A confounding factor may be that very probably a secondary reduction of genome size happened in miniaturized salamanders (Roth et al. 1990).

The described difference in complexity holds for the torus semicircularis and the cerebellum as well. In frogs, the torus is larger and 
G. Roth and W. Walkowiak

Table 3. Averaged genome sizes and amphibian papilla hair cell numbers of different anuran species

\begin{tabular}{|c|c|c|c|c|c|c|}
\hline Family & Species & $\begin{array}{c}\text { Genome } \\
\text { size }\end{array}$ & $\begin{array}{l}\text { Hair cells } \\
\text { (region A }\end{array}$ & $\begin{array}{l}\text { Hair cells } \\
\text { (region B) }\end{array}$ & $\begin{array}{l}\text { Hair cells } \\
\text { (region C) }\end{array}$ & $C /(A+B)$ \\
\hline \multirow[t]{2}{*}{ Bombinatoridae } & B. bombina & 11.38 & 127 & 128 & 33 & 0.26 \\
\hline & B. orientalis & 8.18 & 183 & 173 & 0 & 0.00 \\
\hline Scaphiopodidae & $\begin{array}{l}\text { Scaphiopus } \\
\text { hammondii }\end{array}$ & & 102 & 120 & 85 & 0.38 \\
\hline \multirow[t]{7}{*}{ Ranidae } & Rana sylvatica & 5.93 & 142 & 139 & 262 & 0.93 \\
\hline & R. palustris & 6.31 & 210 & 273 & 421 & 0.87 \\
\hline & R. pipiens & 6.76 & 174 & 214 & 419 & 1.08 \\
\hline & R. sphenocephala & 6.8 & 236 & 277 & 476 & 0.93 \\
\hline & R. clamitans & 6.85 & 175 & 266 & 390 & 0.88 \\
\hline & R. catesbeiana & 7.59 & 300 & 377 & 582 & 0.86 \\
\hline & R. cascadae & 8.01 & 167 & 170 & 316 & 0.94 \\
\hline \multirow[t]{3}{*}{ Hylidae } & Acris crepitans & 4.12 & 128 & 108 & 132 & 0.56 \\
\hline & Hyla versicolor & 4.88 & 128 & 74 & 110 & 0.54 \\
\hline & H. cinerea & 6.69 & 133 & 175 & 212 & 0.69 \\
\hline \multirow[t]{6}{*}{ Bufonidae } & Bufo valliceps & 4.60 & 159 & 145 & 182 & 0.60 \\
\hline & B. marinus & 4.79 & 244 & 173 & 220 & 0.53 \\
\hline & B. americanus & 5.17 & 154 & 94 & 118 & 0.48 \\
\hline & B. cognatus & 5.60 & 98 & 90 & 87 & 0.46 \\
\hline & Bufo alvarius & 5.65 & 197 & 209 & 169 & 0.42 \\
\hline & B. viridis & 5.12 & 179 & 160 & 114 & 0.34 \\
\hline \multirow[t]{2}{*}{ Leptodactylidae } & $\begin{array}{l}\text { Eleutherodactylus } \\
\text { richmondi }\end{array}$ & 3.93 & 196 & 158 & 549 & 1.55 \\
\hline & E. antillensis & 4.19 & 134 & 150 & 379 & 1.33 \\
\hline Microhylidae & G. carolinensis & 4.65 & 200 & 148 & 208 & 0.60 \\
\hline
\end{tabular}

Cell counts are taken from Lewis et al. (1992). Averaged genome size data are taken from Gregory (2005b).

consists of morphologically distinct nuclei and lamination, whereas in urodeles it is small, completely unlaminated, and shows no nucleization. In anurans, the length of the torus is negatively correlated with genome and cell size (i.e., frogs with larger genome and nerve cell sizes have relatively smaller tori).

The increase in nerve cell size in the torus and cerebellum almost certainly occurs because development is much slower in animals with large cell and genome sizes (for review, see Gregory 2005a). During brain development, the caudal part of the rhombencephalic roof and the most rostral parts of the rhombencephalic alar plates differentiate rather late; consequently, the primordia of the torus semicircularis and the cerebellum consist of thin undifferentiated cell layers around stage 29 (Fig. 6) (stages according to Gosner 1960). Because morphological differentiation starts rostralaterally and proceeds caudomedially (see cell migration and lamination in Fig. 6), both the torus and cerebellum are more affected by the late development than is the tectum. We show this by comparing the maximal rostrocaudal extension of the torus semicircularis and dorsoventral dimension of the cerebellum, respectively, with that of the brain in adult specimens, as measured from the olfactory bulb to the sulcus between optic tectum and cerebellum (Fig. 5A).

Most urodeles with generally large genomes and cells compared with frogs do not communicate via acoustic signals, and anuran species with a relatively small torus and large toral cells either do not "call" or produce only simple (i.e., temporally unstructured) calls (Weber and Schumacher 1975, 1976). Large cells have a lower input resistance and different capacitance compared with smaller neurons. The specific membrane capacitance of a neuron influences synaptic efficacy and determines the speed with which electrical signals propagate along dendrites and the soma; 


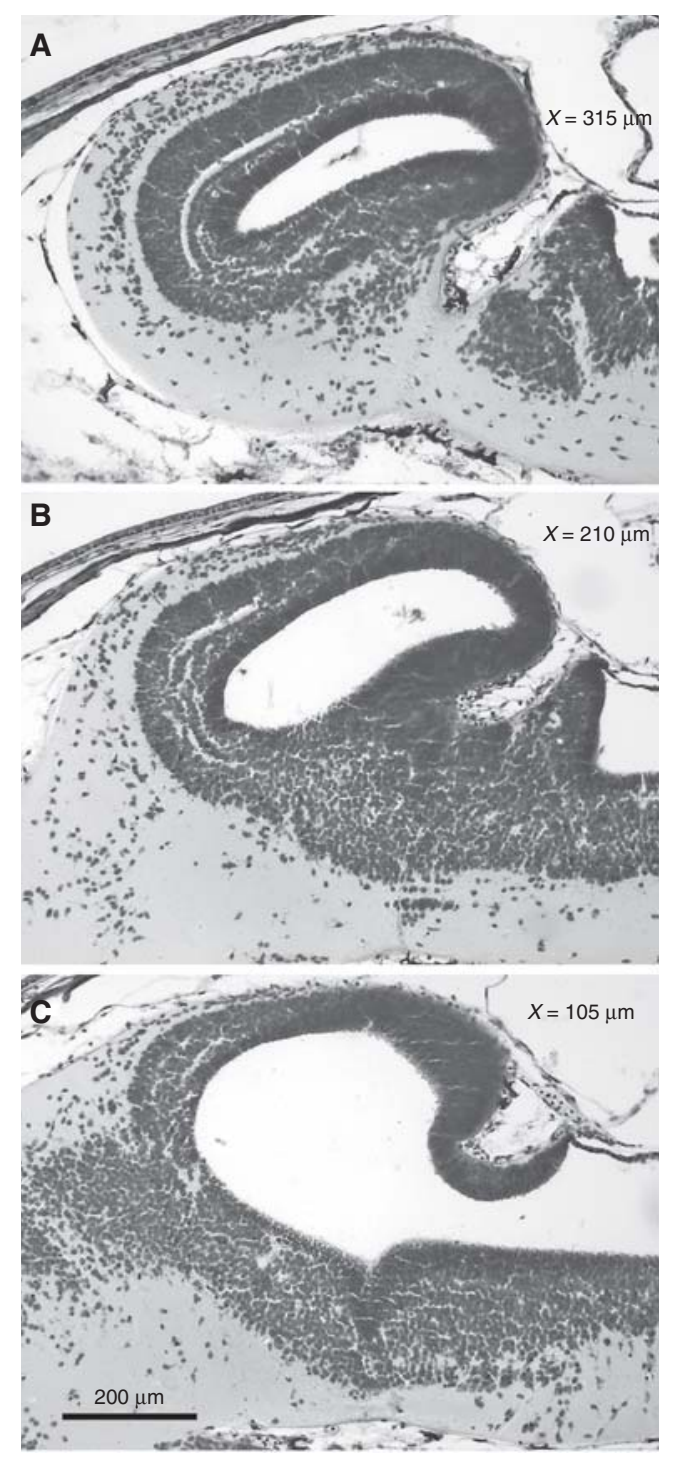

Figure 6. Sagittal sections through a developing Bombina orientalis brain at stage 29. Distances from midline: $(A) 315 \mu \mathrm{m},(B) 210 \mu \mathrm{m}$, and $(C) 105 \mu \mathrm{m}$. TO, tectum opticum; TS, torus semicircularis; Cer, cerebellum.

consequently, there is strong impact on neuronal excitability (Kandel et al. 1991; Mendell 2005). Taking this into account, the behavioral preference of females for different pulse repetition rates in di-, tri-, and tetraploid specimen of the Hyla chrysoscelis complex might be a consequence of different genome sizes, which affect cell dimensions (Keller and Gerhardt 2001; Tucker and Ger-
Genome Size, Cell Size, and Brain Morphology

hardt 2012). Moreover, electrophysiological recordings in the torus of B. bombina (11.38 pg) with large neurons and $R$. temporaria $(4.26 \mathrm{pg})$ with smaller neurons indicate that neurons in B. bombina do not synchronize to high stimulus pulse repetition rates as do neurons in $R$. temporaria (Walkowiak 1980).

The inverse relationship between genome and cells size and the complexity of the anuran auditory system also holds for the auditory periphery, because the number of hair cells in the amphibian papilla is lower in species with larger genomes and cells in comparison to species with smaller genomes and cells.

The situation found in the third order of amphibians, the caecilians, corresponds with that found in urodeles (for details, cf. Schmidt and Wake 1997). Further evidence of the correlation of genome and cell size with brain complexity comes from the dipnoans, all of which have large genomes and cells and relatively simple brain differentiation (Northcutt 1987; Nieuwenhuys et al. 1998). In particular, the lepidosirenids, which have the largest genomes among vertebrates, have the least differentiated brains, with tecta whose simplicity resembles that of salamanders with very large genomes and cells.

\section{Evolutionary Considerations}

In amphibians, an inverse correlation is found between genome and nerve cell size and the size and morphological complexity of important parts of their brains like the tectum mesencephali, the torus semicircularis, and the cerebellum. This correlation does not directly explain causation (i.e., whether an increase in genome and cell size) by means of developmental retardation, induced the observed morphological and - at least in the auditory system - functional simplification, or whether natural selection favoring secondary simplification led to an increase in genome and cell size.

Several investigators have speculated about an adaptive value of the observed increase in genome and cell size in amphibians and lungfishes (Szarski 1970; Chipman et al. 2001; Chipman 2002; Vinogradov 2004). For example, Szarski $(1970,1983)$ suggested that these changes 
can be viewed as an adaptation to life in cold climates (cf. Szarski 1970, 1983). His reasoning is that large cell size is significantly correlated with a reduction in metabolic rates enabling the animals to survive in colder climates. Here, we favor an alternative view that the increase in genome size was nonadaptive in the first place owing to changes in intragenomic control mechanisms, which then induced an increase in cell size, and, consequently, in the other mentioned physiological and developmental parameters, leading, among others, to the observed state of secondary simplification of brain morphology. At least Szarski's idea of a "frugal" metabolic strategy via increase in cell size is contradicted by the fact that the great majority of salamanders, and particularly those with large genomes and cells, do not live in "harsh," but in tropical and subtropical climates, as do all caecilians. In lungfish, the enormous increase in genome size is likewise assumed to be secondary, because all other anamniote vertebrates except amphibians (assumed to be closely related to lungfish) have small to very small genome sizes (Roth et al. 1993; Gregory 2005a). Once this increase occurred, it enabled these animals to survive in African, South American, and Australian environments, in which their habitats dried out seasonally.

In addition, there are many other signs of simplification and retardation within the brains of these amphibians with large genome and cell sizes. Among these are the lack of cell migration in the motor columns of the hindbrain and spinal cord (Roth et al. 1988; Wake et al. 1988) as well as a reduction of the number of ganglion cells and of optic nerve fibers (Linke and Roth 1989, 1990) in salamanders with large genomes and cells. In anurans, there is a reduction of the peripheral auditory system in $B$. orientalis, an anuran with a large genome and cell size (Stadtmüller 1931).

Mueller (2015) discusses the possible mechanisms underlying the apparent coupling between genome size and cells size and possible adaptive and nonadaptive hypotheses of the enormous increase in genome size that has happened in many taxa, including lungfish and salamanders. According to Mueller, germ cells possess a genome-defense system against the increase of transposable elements (TE), which is mediated by the "piRNA" pathway. If this genome defense system limiting TE activity is relaxed, this could have happened either by natural selection, because this leads to an increase in organismal fitness, or by nonadaptive amino acid substitution patterns, in which, via increase in cell size, decrease of metabolic rates, as well as cell division and differentiation rate, constitutes a "burden" for the organism. Mueller proposes the outlines of a procedure for testing the two mentioned hypotheses.

We hypothesize that the increase in genome and cell size in amphibians (although to different degrees in frogs on the one hand and salamanders and caecilians on the other) and in lungfish is a nonselective constraint resulting from intragenomic processes that canalize and slow down the ontogenetic development and, consequently, the evolution of brains, sense organs, and the entire body (Wake and Roth 1989). An extensive phylogenetic comparative study of paedomorphosis in amphibians by Roth et al. (1993) showed that the observed morphological simplicity found in amphibians in general and in salamanders and caecilians in particular is a "derived" and not an ancestral feature, thus indicating that the common ancestors of amphibians had more complex neural and nonneural features than the extant forms.

\section{ACKNOWLEDGMENTS}

We thank David B. Wake (University of California, Berkeley) and H. Carl Gerhardt (University of Missouri) for helpful criticism.

\section{REFERENCES}

* Reference is also in this collection.

Alberch P, Gould SJ, Oster GF, Wake DB. 1979. Size and shape in ontogeny and phylogeny. Paleobiology 5: 296-317.

Chipman AD. 2002. Variation, plasticity and modularity in anuran development. Zoology 105: 97-104.

Chipman AD, Khaner O, Haas A, Tchernov E. 2001. The evolution of genome size: What can be learned from anuran development? J Exp Zool 291: 365-374. 
Dicke U, Roth G. 2007. Evolution of the amphibian nervous system. In Evolution of nervous systems (ed. Kaas JH), Vol. 2, pp. 61-124. Academic, Orlando, FL.

Endepols H, Walkowiak W. 2000. Integration of ascending and descending inputs in the auditory midbrain of anurans. J Comp Physiol A 186: 1119-1133.

Feng AS. 1983. Morphology of neurons in the torus semicircularis of the northern leopard frog, Rana pipiens pipiens. J Morphol 175: 253-269.

Fritz B, Vences M, Glaw F. 1994. Comparative DNA content in Discoglossus (Amphibia, Anura, Discoglossidae). Zool Anz 233: 135-145.

Gosner KL. 1960. A simplified table for staging anuran embryos and larvae. Herpetologica 16: 183-190.

Gould SJ. 1977. Ontogeny and phylogeny. Belknap, Cambridge, MA.

Gregory TR. 2005a. Genome size evolution. In The evolution of the genome (ed. Gregory TR), pp. 3-87. Academic, Orlando, FL.

Gregory TR. 2005b. Animal Genome Size Database, www. genomesize.com.

Hermes DJ, Eggermont JJ, Aertsen AM, Johannesma PI. 1982. Spectro-temporal characteristics of single units in the auditory midbrain of the lightly anaesthetised grass frog (Rana temporaria L.) investigated with tonal stimuli. Hear Res 6: 103-126.

Horner HA, MacGregor H. 1983. C-value and cell volume: Their significance in the evolution and development of amphibians. J Cell Sci 63: 135-146.

Jokusch EL. 1997. An evolutionary correlate of genome size change in plethodontid salamanders. Proc Biol Sci 264: 597-604.

Kandel ER, Schwartz JH, Jessell TM. 1991. Principles of neural science. Elsevier, New York.

Keller MJ, Gerhardt HC. 2001. Polyploidy alters advertisement call structure in gray treefrogs. Proc Biol Sci R Soc 268: $341-345$.

Kimura M. 1983. The neutral theory of molecular evolution. Cambridge University Press, Cambridge, MA.

Lewis ER. 1984. On the frog amphibian papilla. Scan Electron Microsc 1984 (Pt 4): 1899-1913.

Lewis ER, Narins PM. 1999. The acoustic periphery of amphibians: Anatomy and physiology. In Comparative hearing: Fish and amphibians (ed. Fay RR, Popper AN), pp. 101-154. Springer, New York.

Lewis ER, Hecht EI, Narins PM. 1992. Diversity of form in the amphibian papilla of Puerto Rican frogs. J Comp Physiol A 171: 421-435.

Linke R, Roth G. 1989. Morphology of retinal ganglion cells in lungless salamanders (fam. Plethodontidae): An HRP and Golgi study. J Comp Neurol 289: 361-374.

Linke R, Roth G. 1990. Optic nerves in plethodontid salamanders (Amphibia, Urodela): Neuroglia, fiber spectrum and myelination. Anat Embryol 181: 37-48.

Lombard RE. 1977. Comparative morphology of the inner ear in salamanders (Caudata: Amphibia). Cont Vert Evol 2: $1-140$.

Luksch H, Walkowiak W. 1998. Morphology and axonal projection patterns of auditory neurons in the midbrain
Genome Size, Cell Size, and Brain Morphology

of the painted frog, Discoglossus pictus. Hear Res 122: $1-17$.

Mahony M. 1986. "Cytogenetics of myobatrachid frogs." PhD thesis, Macquarie University, Ryde, New South Wales, Australia.

Mendell LM. 2005. The size principle: A rule describing the recruitment of motoneurons. J Neurophysiol 93: 30243026.

Mohneke R. 1983. Tonotopic organisation of the auditory midbrain nuclei of the midwife toad (Alytes obstetricans). Hear Res 9: 91-102.

Morescalchi A. 1990. Cytogenetics and the problem of lissamphibian relationships. In Cytogenetics of amphibians and reptiles (ed. Olmo E), pp. 1-19. Birkhaeuser, Basel, Switzerland.

* Mueller RL. 2015. Genome biology and the evolution of cell-size diversity. Cold Spring Harb Perspect Biol doi: 10.1101/cshperspect.a019125.

Nieuwenhuys R, ten Donkelaar HJ, Nicholson C. 1998. The central nervous system of vertebrates. Springer, New York.

Northcutt RG. 1987. Lungfish neural characters and their bearing on sarcopterygian phylogeny. In The biology and evolution of lungfishes (ed. Bemis WE, et al.), pp. 277297. Alan R. Liss, New York.

Ohno S. 1970. Evolution by gene duplication. Springer, New York.

Olmo E. 1983. Nucleotype and cell size in vertebrates: A review. Bas Appl Histochem 27: 227-256.

Olmo E, Morescalchi A. 1975. Evolution of the genome and cell sizes in salamanders. Experientia 3: 804-806.

Olmo E, Morescalchi A. 1978. Genome and cell size in frogs: A comparison with salamanders. Experientia 34: 44-46.

Potter HD. 1965. Mesencephalic auditory region of the bullfrog. J Neurophysiol 28: 1132-1154.

Roth G. 2013. The long evolution of brains and minds. Springer, Heidelberg, Germany.

Roth G, Wake DB. 1989. Conservatism and innovation in the evolution of feeding in vertebrates. In Complex organismal functions: Integration and evolution in vertebrates (ed. Wake DB, Roth G), pp. 7-22. Wiley, New York.

Roth G, Nishikawa KC, Dicke U, Wake DB. 1988. Topography and cytoarchitecture of the motor nuclei in the brainstem of salamanders. J Comp Neurol 278: 181-194.

Roth G, Rottluff B, Grunwald W, Hanken J, Linke R. 1990. Miniaturization in plethodontid salamanders (Caudata: Plethodontidae) and its consequences for the brain and visual system. Zool J Linn Soc 40: 165-190.

Roth G, Nishikawa KC, Naujoks-Manteuffel C, Schmidt A, Wake DB. 1993. Paedomorphosis and simplification in the nervous system of salamanders. Brain Behav Evol 42: $137-170$.

Roth G, Blanke J, Wake DB. 1994. Cell size predicts morphological complexity in the brains of frogs and salamanders. Proc Natl Acad Sci 91: 4796-4800.

Schmid M, Steinlein C, Friedl R, de Almeida CG, Haaf T, Hillis DM, Duellman WE. 1990. Chromosome-banding in Amphibia. XV: Two types of Y chromosomes and heterochromatin hypervariability in Gastrotheca pseustes (Anura, Hylidae). Chromosoma 99: 413-423. 
G. Roth and W. Walkowiak

Schmidt A, Wake MH. 1997. Cellular migration and morphological complexity in the caecilian brain. J Morph 231: 11-27.

Schneichel W, Schneider H. 1988. Hearing and calls of the banana frog, Afrixalus fornasinii (Bianconi) (Anura: Rhacophoridae). Amphibia-Reptilia 9: 251-264.

Sessions SK, Larson A. 1987. Developmental correlates of genome size in plethodontid salamanders and their implications for genome evolution. Evolution 41: 12391251.

Shen XX, Liang D, Feng YJ, Chen MY, Zhang P. 2013. A versatile and highly efficient toolkit including 102 nuclear markers for vertebrate phylogenomics, tested by resolving the higher level relationship of the Caudata. Mol Biol Evol 30: 2235-2248.

Stadtmüller F. 1931. Varianten im Mittelohrgebiet bei Bombinator (Colummella auris, Hyalbogenspange, Tuba auditiva) [Variations of middle ear cavity in Bombinator]. Gegenbaurs Morphol Jahrb 66: 196-219.

Szarski H. 1970. Changes in the amount of DNA in cell nuclei underlying vertebrate evolution. Nature 226: 651-652.

Szarski H. 1983. Cell size and the concept of wasteful and frugal evolutionary strategies. J Theol Biol 105: 201209.

ten Donkelaar HJ. 1998a. Anurans. In The central nervous system of vertebrates (ed. Nieuwenhuys R, ten Donkelaar HJ, Nicholson C), Vol. 2, pp. 1151-1314. Springer, New York.

ten Donkelaar HJ. 1998b. Urodeles. In The central nervous system of vertebrates (ed, Nieuwenhuys R, ten Donkelaar HJ, Nicholson C), Vol. 2, pp. 1045-1150. Springer, New York.

Tucker MA, Gerhardt HC. 2012. Parallel changes in mateattracting calls and female preferences in autotriploid tree frogs. Proc R Soc B 279: 1583-1587.
Vinogradov AE. 2004. Evolution of genome size: Multilevel selection, mutation bias or dynamical chaos? Curr Opin Genet Dev 14: 620-626.

Wake DB. 1966. Comparative osteology and evolution of the lungless salamanders, family Plethodontidae. Mem South California Acad Sci 4: 1-111.

Wake DB, Roth G. 1989. The linkage between ontogeny and phylogeny in the evolution of complex systems. In Complex organismal functions: Integration and evolution in vertebrates (ed. Wake DB, Roth G), pp. 361-377. Wiley, New York.

Wake DB, Nishikawa KC, Dicke U, Roth G. 1988. Organization of the motor nuclei in the cervical spinal cord of salamanders. J Com Neurol 278: 195-208.

Walkowiak W. 1980. The coding of auditory signals in the torus semicircularis of the fire-bellied toad and the grass frog: Responses to simple stimuli and to conspecific calls. J Comp Physiol A 138: 131-148.

Walkowiak W, Luksch H. 1994. Sensory motor interfacing in acoustic behavior of anurans. Amer Zool 34: 685695.

Weber E, Schumacher R. 1975. Der Aufbau der Abwehrrufe des Kammolches (Triturus cristatus) und des Fadenmolches (Triturus helveticus) (Amphibia, Caudata, Salamandridae). Salamandra 11: 119-129.

Weber E, Schumacher R. 1976. Der Aufbau der Abwehrrufe des Bergmolches Triturus alpestris Laurenti (Amphibia, Urodela). Zool Anz 196: 61-66.

Wilczynski W, Endepols H. 2007. Central auditory pathways in anuran amphibians: The anatomical basis of hearing and sound commmunication. In Hearing and sound communication in amphibians (ed. Narins PM, Feng AS, Fay RR, Popper AN), pp. 221-249. Springer, New York.

Wilczynski W, Ryan MJ. 2010. The behavioral neuroscience of anuran social signal processing. Curr Opin Neurobiol 20: $754-763$. 


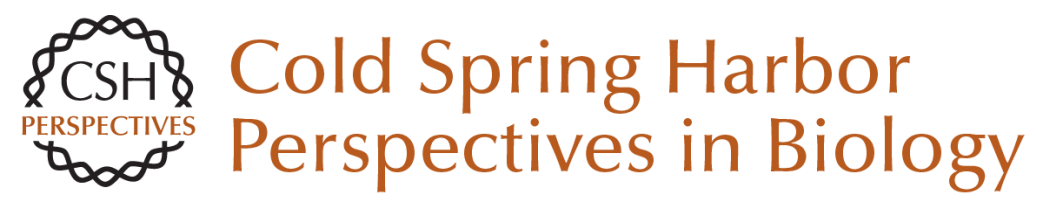

\section{The Influence of Genome and Cell Size on Brain Morphology in Amphibians}

Gerhard Roth and Wolfgang Walkowiak

Cold Spring Harb Perspect Biol 2015; doi: 10.1101/cshperspect.a019075 originally published online August 10, 2015

\section{Subject Collection Size Control in Biology: From Organelles to Organisms}

\section{Cell-Size Control}

Amanda A. Amodeo and Jan M. Skotheim

Indeterminate Growth: Could It Represent the

Ancestral Condition?

Iswar K. Hariharan, David B. Wake and Marvalee H. Wake

The Systemic Control of Growth

Laura Boulan, Marco Milán and Pierre Léopold

Genome Biology and the Evolution of Cell-Size

Diversity

Rachel Lockridge Mueller

Size Scaling of Microtubule Assemblies in Early Xenopus Embryos Timothy J. Mitchison, Keisuke Ishihara, Phuong Nguyen, et al.

The Influence of Genome and Cell Size on Brain Morphology in Amphibians

Gerhard Roth and Wolfgang Walkowiak

The Opposing Actions of Target of Rapamycin and AMP-Activated Protein Kinase in Cell Growth Control

Sravanth K. Hindupur, Asier González and Michael N. Hall

Small but Mighty: Cell Size and Bacteria

Petra Anne Levin and Esther R. Angert
Mechanical Forces and Growth in Animal Tissues Loïc LeGoff and Thomas Lecuit

Biological Scaling Problems and Solutions in

Amphibians

Daniel L. Levy and Rebecca Heald

Intracellular Scaling Mechanisms

Simone Reber and Nathan W. Goehring

Growing an Embryo from a Single Cell: A Hurdle

in Animal Life

Patrick H. O'Farrell

Organ-Size Regulation in Mammals

Alfredo I. Penzo-Méndez and Ben Z. Stanger

Size Control in Plants--Lessons from Leaves and Flowers

Hjördis Czesnick and Michael Lenhard

Nuclear DNA Content Varies with Cell Size across

Human Cell Types

James F. Gillooly, Andrew Hein and Rachel

Damiani

Subcellular Size

Wallace F. Marshall

For additional articles in this collection, see http://cshperspectives.cshlp.org/cgi/collection/

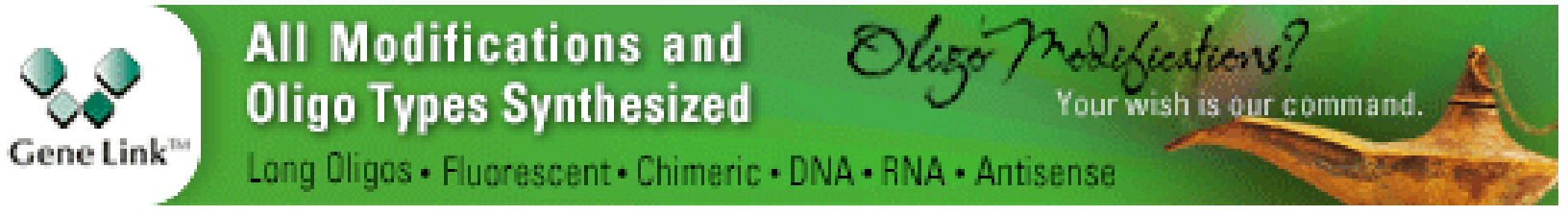

Copyright @ 2015 Cold Spring Harbor Laboratory Press; all rights reserved 